\title{
Seasonal variation in the relative utilization of carbon and nitrogen by the mussel Mytilus edulis: budgets, conversion efficiencies and maintenance requirements
}

\author{
A. J. S. Hawkins \& B. L. Bayne \\ N.E.R.C., Institute for Marine Environmental Research, Prospect Place, The Hoe, Plymouth PL1 3DH, Devon, England
}

\begin{abstract}
Elemental balances for carbon and nitrogen in an open-shore population of the bivalve mollusc Mytilus edulis underwent seasonal changes more characteristic of time-averaged than immediate optimization. Budgets emphasized the significance of shell and byssus towards both the carbon ( 8 and $44 \%$, respectively) and nitrogen ( 8 and $21 \%$, respectively) within total production, and indicated that between at least 20 and $67 \%$ of the nitrogen in faeces may be of metabolic origin. In addition to differing absorption rates, pronounced seasonal variations of net growth efficiency were effected for each element by changes in metabolic demand that not only reflected requirements per se, but also the 'gross efficiencies' with which absorbed nutrients were used to offset net deficits. Changes of 'gross efficiency' were at least partially due to a variable subsidization of maintenance requirements from pre-stored reserves, rather than to possible variations of metabolic efficiency alone. Although net growth efficiencies for nitrogen consistently exceeded those for carbon, the associated seasonal patterns of utilization were different for each element, and are discussed in relation to physiological, storage and reproductive cycles documented elsewhere. Ratios between coincident maintenance requirements for the utilizable carbon and nitrogen in the alga Phaeodactylum tricornutum varied from $12: 1$ during summer to as much as $83: 1$ in winter. Further, relative to carbon, mussels regularly absorbed higher proportions of their maintenance requirements for nitrogen. These results, together with known fluctuations of nutrients in the natural environment, imply that there may have been transient limitation of organic processes by the available carbon, and emphasize the need for a multielemental approach in future studies of bivalve nutrition.
\end{abstract}

\section{INTRODUCTION}

Filter-feeding bivalves are of widespread significance as biogeochemical agents in nearshore communities (Kuenzler 1961a, b, Kautsky 1981, Jordan \& Valiela 1982). There remains, however, little contemporary understanding concerning either the regulation of resource acquisition or the relative utilization of 'essential' elements (Russell-Hunter 1970) absorbed by these or indeed any marine invertebrate. Most previous studies on trophic relations and resource transformations of bivalves have been undertaken in terms of calories (reviewed by Bayne \& Newell 1983, see also Winter et al. 1984) or carbon (Kofoed 1975, Gilfillan et al. 1976, Kiorboe et al. 1980, Gallager et al. 1981, Seiderer et al. 1982), when the individual has been assumed to maximize energy/nutrient gain under all circumstances. In this context, Hawkins et al. (1985) have demonstrated marked seasonal variations of absorption by the blue mussel Mytilus edulis which appear endogenously regulated in a manner more indicative of time-averaged than immediate optimization. Further, relative to carbon, nitrogen may better represent one of the specific compounds with potential to limit production (Liebig 1840), being utilized primarily in structural material rather than energy reserves. Flows of carbon/energy within coastal ecosystems are often limited by the availability of nitrogen (reviewed by Mann 1982), and production by many marine invertebrates correlates with the amount of protein ingested (reviewed by Roman 1983). As emphasized by Mann (1982), knowledge of both carbon/energy and nitrogen flows is thus fundamental to any understanding of the fluctuating productivity that 
is so often apparent. Nevertheless, few workers have investigated nitrogen/protein balance in bivalves (Bayne \& Scullard 1977, Bayne \& Widdows 1978, Gallager et al. 1981, Jordan \& Valiela 1982), and none has ascertained nitrogen absorption directly. Similarly, little is known concerning the relative maintenance requirements for absorbed nutrients, and nothing of seasonal influences upon those requirements.

This study questions the assumption that nutrient gain and allocation are always maximized in the shortterm and compares seasonal variation in the relative utilization of carbon and nitrogen in an open-shore population of Mytilus edulis that is naturally subjected to seasonal fluctuation in the supply of food. In addition, we assess the extent to which changing rates of absorption, varying requirements for exogenous nutrients, and the associated degree to which both the carbon and nitrogen absorbed were utilized to offset net deficits affected the net growth efficiencies for each element. Simultaneous nitrogen and carbon budgets are discussed in relation to physiological, reproductive and storage cycles documented previously (Hawkins et al. 1983, 1985, Hawkins \& Bayne 1984, Hawkins 1985), and with particular respect to the potential limitation of production by exogenous availability of either element.

\section{MATERIAL AND METHODS}

Collection and maintenance. Mytilus edulis L. of 45 to $57 \mathrm{~mm}$ shell length were gathered at about low water tide level from Whitsand Bay, southwest England, in March, June and October 1981. Subsequent conditions of feeding and starvation throughout 5 to 6 wk periods of laboratory acclimation, together with methods of culturing ${ }^{15} \mathrm{~N}:{ }^{14} \mathrm{C}$-labelled Phaeodactylum tricornutum, administering this alga to acclimated mussels, and determining isotopic enrichments within samples are described by Hawkins \& Bayne (1984) and Hawkins et al. $(1983,1985)$. These authors have also described methods for estimation of elemental composition, ingestion rate, 'net' and 'gross' absorption efficiencies, oxygen consumption and excretion that are used here to compute elemental fluxes of both carbon and nitrogen

Carbon balance. The quantity of carbon consumed by mussels was calculated as the product of ingestion ( $\mu \mathrm{g}$ dry $\mathrm{wt} \mathrm{h}^{-1}$ ) and mean organic carbon content of Phaeodactylum tricornutum (42.78 $\pm 0.09 \%$, $2 \mathrm{SE}$, $n=5$ ). This value, when multiplied by the net absorption efficiency, yields net carbon absorption $\left(\mu \mathrm{g} \mathrm{C}^{-1}\right)$. Net absorption efficiencies for carbon were assumed equivalent to those derived using the Conover (1966) ratio, as has been verified for the mussel Aulacomya ater (Stuart et al. 1982). Carbon respired ( $\mu \mathrm{g} \mathrm{Ch}^{-1}$; mean \pm range) was calculated from rates of oxygen consumption ( $\mathrm{ml} \mathrm{O}_{2} \mathrm{~h}^{-1}$ ) (cf. methods of Gilfillan et al. 1976, Rodriguez-Ortega \& Day 1978, Gallager et al. 1981) assuming a range of respiratory quotients between $0.71\left(1 \mathrm{ml} \mathrm{O}_{2}=0.38 \mathrm{mg} \mathrm{C}\right)$ and $1.0(1 \mathrm{ml} \mathrm{O}$ $=0.53 \mathrm{mg} \mathrm{C}$ ). This range accounted for the catabolism of carbohydrate, lipid or protein, including any mixture thereof (Schmidt-Nielsen 1977). Net carbon balance (mean \pm range) was then computed as net carbon absorption minus carbon respired.

Nitrogen balance. Net balances of nitrogen were derived in a manner essentially similar to those for carbon. The mean organic nitrogen content for Phaeodactylum tricornutum was $6.64 \pm 0.66 \%$ ( $\pm 2 \mathrm{SE}_{1} n=12$ ). Both net absorption efficiencies and losses of nitrogen within excreted ammonia were determined directly. Net nitrogen balance was computed as net nitrogen absorption minus nitrogen excreted. In addition, differences between coincident measures of the 'net' and 'gross' efficiencies of nitrogen absorption were calculated to enable estimations of the 'metabolic faecal nitrogen' ( $\mu \mathrm{g} \mathrm{N} \mathrm{h}^{-1}$ ) (cf. Calow $\&$ Fletcher 1972), representing nitrogen of endogenous origin that is lost from the individual as faeces.

Byssus threads. The production of byssal threads was measured as both $\mu \mathrm{g} C$ and $\mu \mathrm{g} \mathrm{N}$ mussel ${ }^{-1} \mathrm{~h}^{-1}$ during March and June 1981. All byssus was cut from mussels ( $n=6$ to 8 ), and the secreted threads collected from individuals $36 \mathrm{~d}$ later. Immediately following collection, threads were freeze-dried and weighed before determining the carbon and nitrogen contents within replicated subsamples using a Carlo Erba elemental analyser with acetanilide as a standard.

${ }^{15} \mathrm{~N}$ and ${ }^{14} \mathrm{C}$ incorporation. The relative incorporation of ${ }^{15} \mathrm{~N}$ and ${ }^{14} \mathrm{C}$ within tissues and shells of fed mussels ( $n=3$ to 5 ) was measured at intervals up to $23 \mathrm{~d}$ after the ingestion of labelled Phaeodactylum tricornutum in March and June 1981. Following excision, the total soft tissues were subdivided into digestive gland, mantle and 'remainder', and the shells thoroughly washed with distilled water. Samples were subsequently freeze-dried, weighed, ground to a homogeneous powder and stored within airtight glass vials at $-90^{\circ} \mathrm{C}$ prior to isotopic analyses (Hawkins 1983).

Seasonal elemental budgets. The results were used to construct seasonal budgets for nitrogen and carbon. Each component was computed as a percentage of ingestion rate and expressed in terms of (i) net growth efficiency (the net balance, expressed as a proportion of the coincident ration absorbed), (ii) 'gross efficiency' (the increment in net balance between starved and fed individuals, expressed as a proportion of the associated ration absorbed by fed individuals) and (iii) instantaneous maintenance requirements' (the ration neces- 
sary to sustain zero net balance at a given moment in time, estimated by computing ration-specific increments of net balance between starved and fed individuals)

\section{RESULTS}

The estimated net balances, net growth efficiencies, 'gross efficiencies' and 'instantaneous maintenance requirements' for both carbon and nitrogen are shown in Tables 1 and 2, respectively. Negative elemental balances were recorded in winter (March; $-15.5 \mu \mathrm{g}$ $\mathrm{Ch}^{-1}$ and $-0.58 \mu \mathrm{g} \mathrm{Nh}^{-1}$ ) and autumn (October;

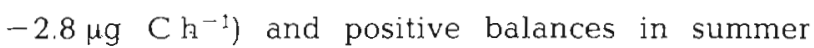
(June; $+36.4 \mu \mathrm{g} \mathrm{Ch}^{-1}$ and $+9.5 \mu \mathrm{g} \mathrm{N} \mathrm{h}^{-1}$ ). It is, however, notable that the net balance of nitrogen remained positive during autumn $\left(+8.09 \mu \mathrm{g} \mathrm{h}^{-1}\right)$.

Seasonal net growth efficiencies for nitrogen consistently exceeded those for carbon; the efficiencies for each element varied over wide ranges, and were lowest during winter (Table $1 \& 2$ ). Quite apart from the influence of differing absorption rates, these variations of net growth efficiency were clearly effected by seasonal changes of metabolic demand and the associated gross efficiency with which each element was utilized from the available ration to offset net deficits. The

Table 1. Mytilus edulis. Computation of net balances, net growth efficiencies, gross efficiencies and maintenance requirements for carbon among 45 to $57 \mathrm{~mm}$ shell-length mussels either fed or starved during acclimation in March, June and October 1981

\begin{tabular}{|c|c|c|c|c|c|c|c|c|c|}
\hline $\begin{array}{l}\text { Date and } \\
\text { nutritional } \\
\text { status }\end{array}$ & $\begin{array}{l}\text { Ingested } \\
\text { ration } \\
\left(\mu \mathrm{gCh}^{-1}\right)\end{array}$ & $\begin{array}{c}\text { Net } \mathrm{C} \\
\text { absorption } \\
\left(\mu \mathrm{C}^{-1}\right)\end{array}$ & $\begin{array}{c}\mathrm{CO}_{2} \text { equivalents } \\
\text { of oxygen } \\
\text { consumed } \\
\left(\mu \mathrm{C} \mathrm{h} \mathrm{h}^{-1}\right)\end{array}$ & $\begin{array}{c}\text { Net } C \\
\text { balance } \\
\left(\mu \mathrm{g} \mathrm{Ch} \mathrm{Ch}^{-1}\right)\end{array}$ & $\begin{array}{c}\text { Change } \\
\text { in } \\
\text { body-C } \\
\left(\% \mathrm{~d}^{-1}\right)\end{array}$ & $\begin{array}{c}\text { Net } \\
\text { growth } \\
\text { efficiency } \\
(\%)\end{array}$ & $\begin{array}{c}\text { Gross } \\
\text { efficiency } \\
(\%)\end{array}$ & $\begin{array}{c}\text { Maintenan } \\
\text { Ingested } \\
\left(\mu \mathrm{C} \mathrm{C} \mathrm{h}^{-1}\right)\end{array}$ & $\begin{array}{l}\text { quirements } \\
\text { Absorbed } \\
\left(\mu \mathrm{g} \mathrm{Ch}^{-1}\right)\end{array}$ \\
\hline \multicolumn{10}{|l|}{ March } \\
\hline $\begin{array}{l}\text { Fed } \\
\text { Starved }\end{array}$ & $\begin{array}{l}72.7 \\
-\end{array}$ & $\begin{array}{c}27.3 \\
-\end{array}$ & $\begin{array}{l}42.8 \pm 6.9 \\
16.6 \pm 2.7\end{array}$ & $\begin{array}{l}-15.5 \pm 6.9 \\
-16.6 \pm 2.7\end{array}$ & $\begin{array}{l}-0.15 \\
-0.17\end{array}$ & $\begin{array}{c}-56.8 \\
-\end{array}$ & $\begin{array}{c}+4.0 \\
-\end{array}$ & 1097.1 & 412.0 \\
\hline \multicolumn{10}{|l|}{ June } \\
\hline $\begin{array}{l}\text { Fed } \\
\text { Starved }\end{array}$ & $\begin{array}{c}231.0 \\
-\end{array}$ & $\begin{array}{c}120.6 \\
-\end{array}$ & $\begin{array}{l}84.2 \pm 13.7 \\
63.1 \pm 10.2\end{array}$ & $\begin{array}{l}+36.4 \pm 13.7 \\
-63.1 \pm 10.2\end{array}$ & $\begin{array}{l}+0.23 \\
-0.38\end{array}$ & $\begin{array}{c}+30.2 \\
-\end{array}$ & $\begin{array}{c}+82.5 \\
-\end{array}$ & 146.5 & 76.5 \\
\hline $\begin{array}{l}\text { October } \\
\text { Fed } \\
\text { Starved }\end{array}$ & $\begin{array}{c}132.6 \\
-\end{array}$ & $\begin{array}{l}72.7 \\
-\end{array}$ & $\begin{array}{l}75.5 \pm 14.9 \\
67.7 \pm 11.0\end{array}$ & $\begin{array}{l}-2.8 \pm 14.9 \\
-67.7 \pm 11.0\end{array}$ & $\begin{array}{l}-0.02 \\
-0.52\end{array}$ & $\begin{array}{c}-3.8 \\
-\end{array}$ & $\begin{array}{c}+89.3 \\
-\end{array}$ & 138.3 & 75.8 \\
\hline $\begin{array}{l}{ }^{a} \text { Values pr } \\
{ }^{b} \text { Note a dis } \\
\text { gross effici } \\
\text { these as } \mathrm{f} \\
=[(-15.5)\end{array}$ & $\begin{array}{l}\text { sented } \pm \\
\text { tinction he } \\
\text { ncy were } \\
\text { actions of } \\
(-16.6)] /\end{array}$ & $\begin{array}{l}\text { the range } \\
\text { re from the } \\
\text { derived by } \\
f \text { the asso } \\
27.3=0.04\end{array}$ & $\begin{array}{l}\text { computed assum } \\
\text { ' gross growth } \\
\text { computing incre } \\
\text { tiated net carl } \\
4\end{array}$ & $\begin{array}{l}\text { ling respirator } \\
\text { fficiency of T } \\
\text { ments in carbo } \\
\text { pon absorptio }\end{array}$ & $\begin{array}{l}\text { quotients } \\
\text { mpson \& } \\
\text { balance } \\
\text { for fed }\end{array}$ & $\begin{array}{l}\text { between } 0 \\
\text { Bayne ( } 197 \\
\text { between fed } \\
\text { individual }\end{array}$ & $\begin{array}{l}0.72 \text { and } 1 \\
74) \text { and ot\} } \\
\text { d and stary } \\
\text { ls; thus, }\end{array}$ & $\begin{array}{l}\text { The pre } \\
\text { conditior } \\
\text { March, }\end{array}$ & $\begin{array}{l}\text { timates of } \\
\text { expressing } \\
\text { efficiency }\end{array}$ \\
\hline
\end{tabular}

Table 2. Mytilus edulis. Computation of net balances, net growth efficiencies, gross efficiencies and maintenance requirements for nitrogen among 45 to $57 \mathrm{~mm}$ shell-length mussels either fed or starved during acclimation in March, June and October 1981

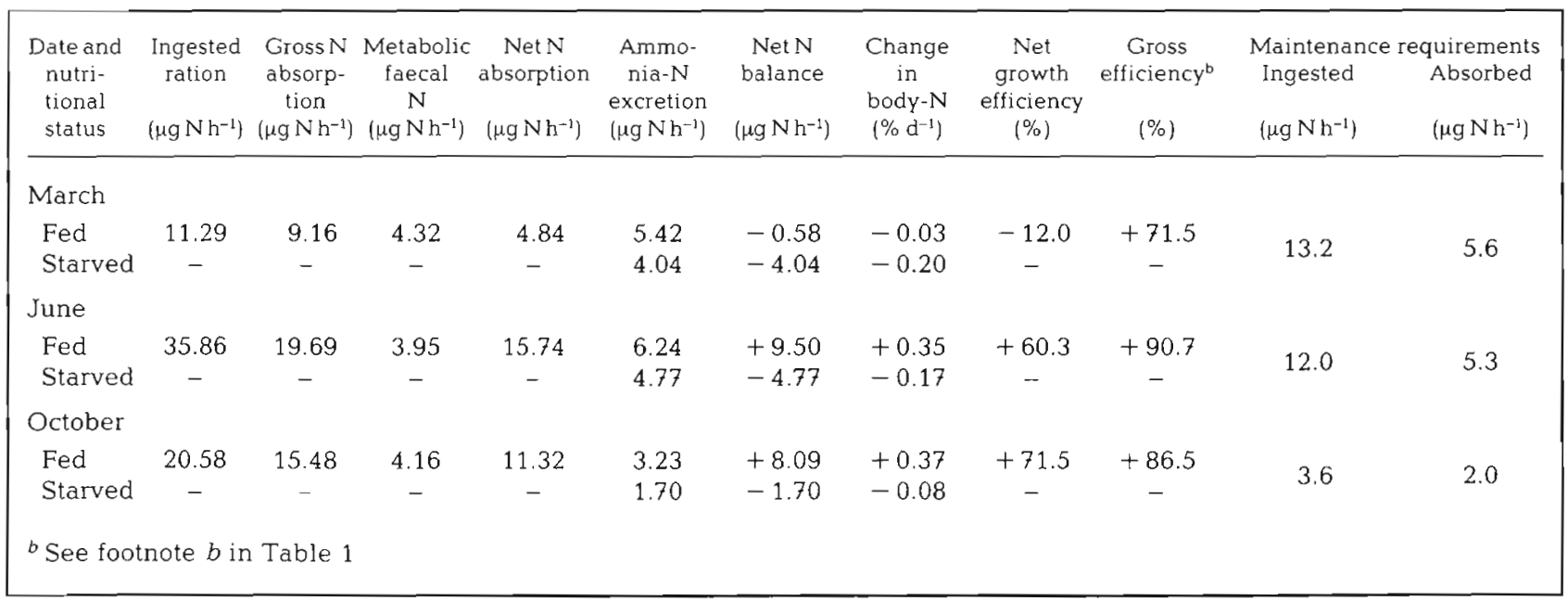


Table 3. Mytilus edulis. Secretion of byssal threads by 45 to $57 \mathrm{~mm}$ shell-length mussels in March and June 1981. Values are means $\pm 2 \mathrm{SE}$ for $n$ mussels, where dry weights of byssal threads were converted to units of nitrogen and carbon using measured elemental contents of $14.38 \%(2 \mathrm{SE}=0.52, n=8)$ and $54.71 \%(2 \mathrm{SE}=0.95, n=8)$, respectively

\begin{tabular}{|lcccc|}
\hline Month & $n$ & \multicolumn{2}{c}{ Byssal thread secretion $\left(\mu \mathrm{g} \mathrm{h}^{-1}\right.$ mussel $\left.{ }^{-1}\right)$} \\
& & Dry weight & Nitrogen & Carbon \\
\hline March & 6 & $5.15 \pm 1.79$ & $0.74 \pm 0.30$ & $2.82 \pm 1.04$ \\
June & 7 & $5.29 \pm 2.06$ & $0.76 \pm 0.32$ & $2.89 \pm 1.21$ \\
\hline
\end{tabular}

pattern of such changes was different for each element, and appeared more extreme for carbon than nitrogen. Indeed, whereas ingested maintenance requirements for carbon were 7.5 to 7.9 times higher during winter than in summer or autumn, demands for nitrogen were recorded during both winter and summer at levels which were only 3.3 to 3.7 times greater than in autumn. Coincident gross efficiencies for each element were roughly equivalent during summer and autumn ( 82 to $90 \%$ ), but displayed winter minima of $71 \%$ for nitrogen and as little as $4 \%$ for carbon (Table $1 \& 2$ ).

There was no evidence for seasonal variation between rates of byssal thread production (Table 3 ) ( $t$-test value $t_{\mathrm{s}}=0.0115$ for $11 \mathrm{DF}, P>0.05$ ). These rates, measured using mussels of 0.33 to $0.71 \mathrm{~g}$ dry tissue weight, compare favourably with those of 2.5 to $5.8 \mu \mathrm{g}$ dry byssus $\mathrm{h}^{-1}$ recorded for smaller Mytilus edulis of 0.20 to $0.27 \mathrm{~g}$ tissue weight by Kiorboe et al. (1981).

Percentages of the isotopes ingested that were incorporated within shells are presented in Table 4. The relative incorporations of carbon and nitrogen appeared similar. Greater proportional uptake of each element into the shell of mussels during summer, when feeding was maximal (Table 1 \& 2), is consistent with there being a positive correlation between gain in shell weight and the amount of food ingested by Mytilus edulis (Winter 1974, 1976).

Time-series for the percentage contributions from each tissue division towards isotopic excesses within the total soft tissues are shown in Fig. 1. Significant

Table 4. Mytilus edulis. Percentages of ingested isotopes that were incorporated within shell matrices of 45 to $57 \mathrm{~mm}$ shelllength mussels in March and June 1982. Values are means \pm range for $n$ mussels

\begin{tabular}{|llcc|}
\hline Month & $n$ & \multicolumn{2}{c|}{ Percentage incorporation } \\
& & ${ }^{15} \mathrm{~N}$ & ${ }^{14} \mathrm{C}$ \\
\hline March & 3 & $3.49 \pm 0.11$ & $2.86 \pm 0.53$ \\
June & 4 & $5.47 \pm 0.79$ & $6.97 \pm 0.27$ \\
\hline
\end{tabular}
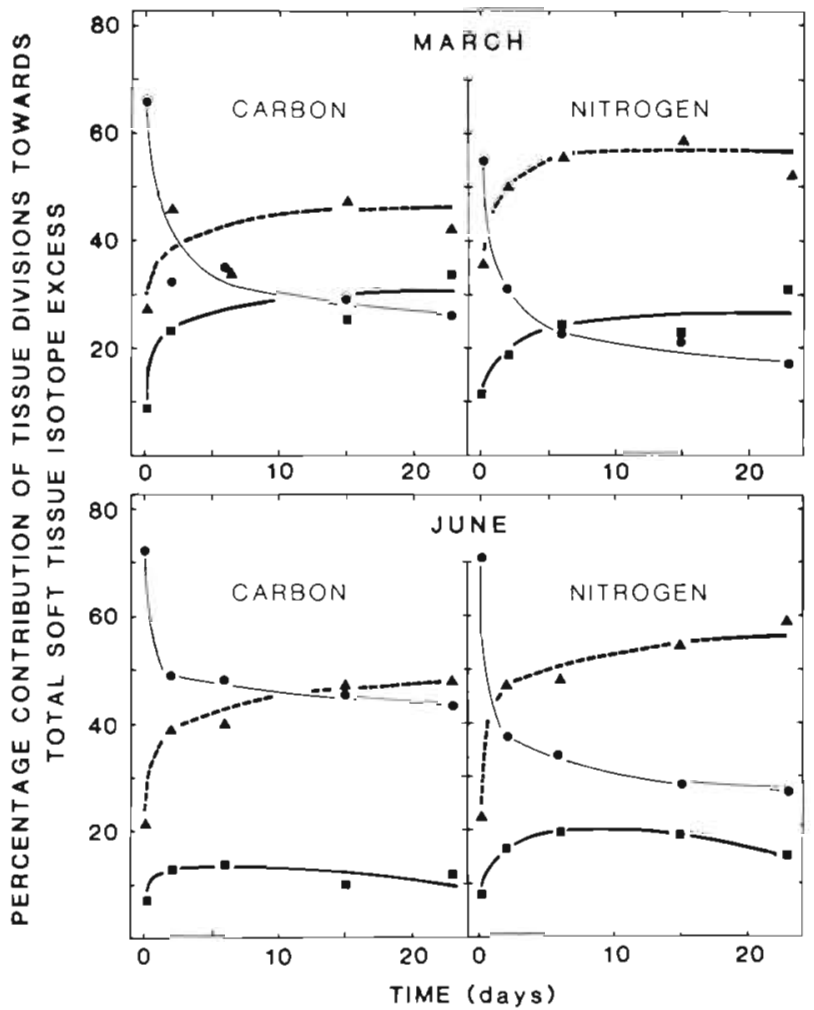

Fig. 1. Mytilus edulis. Percentage contributions of digestive

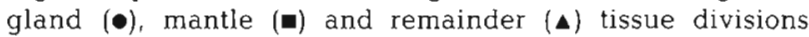
towards both the atom excess ${ }^{15} \mathrm{~N}(\mu \mathrm{g})$ and ${ }^{14} \mathrm{C}$ (DPM) within total soft tissues of 45 to $57 \mathrm{~mm}$ shell-length mussels at intervals up to $23 \mathrm{~d}$ after ingesting labelled alga in March and June, 1981. Curves fitted by eye

differences were apparent between the internal translocation of each element. In particular, relative to ${ }^{15} \mathrm{~N}$, a consistently higher percentage of ${ }^{14} \mathrm{C}$ was incorporated within the digestive gland, and vice versa for the remainder tissue division (Table 5, Fig. 1). This clearly reflects the role played by digestive tissues in the storage of lipid and carbohydrate reserves (Gabbott \& Bayne 1973, Hawkins et al. 1985). Further, compared with ${ }^{14} \mathrm{C}$, greater proportional allocation of ${ }^{15} \mathrm{~N}$ to the

Table 5. Mytilus edulis. Results of $t$-tests for paired comparisons (Sokal \& Rohlf 1969) between coincident time-series for the percentage contributions of digestive gland, mantle and remainder tissue divisions towards the atom excess ${ }^{15} \mathrm{~N}$ and ${ }^{14} \mathrm{C}$ within total soft tissues after ingesting labelled alga in March and June, 1981 Data are illustrated in Fig. 1 ts: Students $t$-value; $P$ : the probability that the mean of differences between pairs of data is different from zero at $n-1=4 \mathrm{DF}$

\begin{tabular}{|lccccc|}
\hline Tissue division & \multicolumn{2}{c}{ March } & \multicolumn{2}{c|}{ June } \\
& $t_{\mathrm{s}}$ & $P$ & $t_{\mathrm{s}}$ & $P$ \\
\hline Digestive gland & 4.031 & $<0.02$ & 4.462 & $<0.02$ \\
Mantle & 1.539 & $\mathrm{NS}$ & 3.199 & $<0.05$ \\
Remainder & 3.739 & $<0.05$ & 4.397 & $<0.02$ \\
\hline
\end{tabular}


mantle in summer, but not winter (Table 5, Fig. 1), was probably associated with the seasonal deposition of protein within adipogranular cells (Hawkins et al. 1985, cf. Houteville 1974, Mathieu 1979). Although not showing clear differences in the flow of each element, gametogenic demands were evidenced during winter when, relative to summer, a higher percentage of absorbed ${ }^{14} \mathrm{C}$ ( $t$-test value for paired comparisons $t_{\mathrm{s}}=$ $3.732, \mathrm{DF}=4, P<0.05$; equivalent $t_{\mathrm{s}}$ value for nitrogen $=2.210, \mathrm{DF}=4, P<0.10>0.05)$ was transferred to the mantle (Fig. 1).
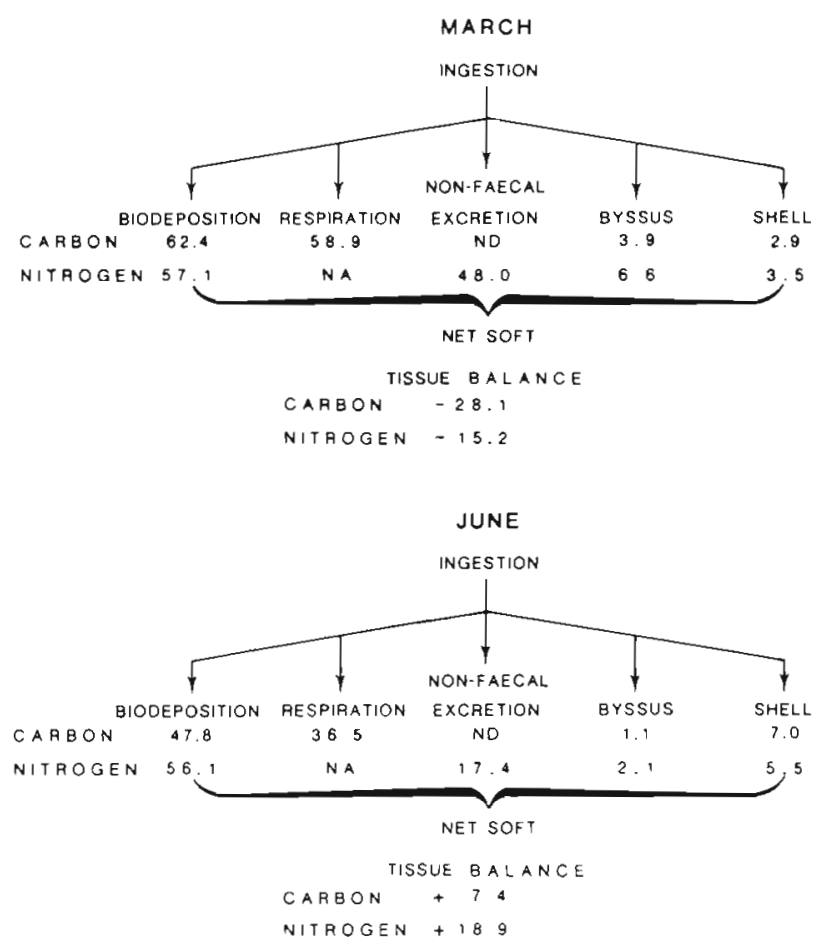

Fig. 2. Mytilus edulis. Carbon and nitrogen budgets for 45 to $57 \mathrm{~mm}$ shell-length mussels in March and June, 1981. NA: not applicable; ND: not determined

Major components of the seasonal nitrogen and carbon budgets are shown in Fig. 2. More than $48 \%$ of each element consumed was voided as faeces. Within these faeces, however, 'metabolic faecal nitrogen' ranged between 731 and 2,451 mg nitrogen per $100 \mathrm{~g}$ of dry diet ingested. These values are substantially higher than those of $<215 \mathrm{mg} 100 \mathrm{~g}^{-1}$ diet reported for other species that include prawns (Forster \& Gabbott 1971), fish (Nose 1967, Jauncey 1982), rats (Williams \& Senior, 1981) and man (Maynard \& Loosli 1969). Complementary evidence for the significant presence of metabolic material within faeces has stemmed from patterns of isotope defecation, from which Hawkins \& Bayne (1984) estimated that the excretion of metabolised isotope constituted about $15 \%$ of all faecal ${ }^{15} \mathrm{~N}$ in summer. An equivalent calculation, based upon data for net and gross absorption during summer (Table 2), is consistent with this estimate, indicating that metabolic excretion contributed (3.95/ $[35.86-15.74]) \times 100=20 \%$ towards faecal nitrogen. This contribution increased to as much as (4.32/ $(11.29-4.84)) \times 100=67 \%$ of faecal nitrogen during winter.

Percentages of both the ingested carbon respired and the ingested nitrogen excreted were also considerably higher in winter (59 and $48 \%$, respectively) than in summer (36 and $17 \%$, respectively). Associated with such changes, gross production efficiencies ([byssus + shell + soft tissue]/ingestion) for carbon and nitrogen alternated from negative values during winter ( -16 and $-32 \%$, respectively) to become positive in summer (19 and $32 \%$, respectively). Byssus and shell each accounted for substantial proportions of both the carbon ( 8 and $44 \%$, respectively) and nitrogen ( 8 and $21 \%$, respectively) within total production (byssus + shell + soft tissue) during the summer period of net soft tissue growth (Table $1 \& 2$, Fig. 2).

\section{DISCUSSION}

Perhaps because it is not generally appreciated that byssal threads are comprised largely of proteins (Waite 1983), and because organic matter in most bivalve shells amounts to less than $5 \%$ by weight (Price et al. 1976. Cameron et al. 1979), these materials have often been ignored in production studies. Our findings for Mytilus edulis, however, together with those for the mussels Geukensia demissa (Kuenzler 1961a, Jordan \& Valiela 1982) and Perna perna (Berry 1978), have shown that both shell and byssus may represent substantial fractions of annual production. Accordingly, just as these materials should not be underestimated in studies of standing stock biomass (Price et al. 1976, Paterson 1982), they clearly warrant consideration as significant components of production.

Estimates that more than $48 \%$ of both the carbon and nitrogen consumed were expelled as faeces reflect the potential role of mussels as biogeochemical agents. At least $20 \%$ of the nitrogen within these faeces was shown to be of metabolic origin, rather than being the unabsorbed remnants of ingestion alone; we are not aware that this phenomenon has previously been quantified for any bivalve. Among gastropods, the faecal mucous envelope may account for 9 to $10 \%$ of both the carbon and nitrogen within faeces (Edwards \& Welsh 1982). Mytilus edulis not only produces mucousbound faecal ribbons (Dinamani 1969, Arakawa 1970), but may 'incubate' bacteria within the digestive system (Prieur 1981), and reject the undigested remnants of intracellular lysosomal activity within residual 
bodies from the digestive cells (Platt 1971). In addition, periods of net nitrogen loss to the faeces during winter coincided with elevated rates of ammonia excretion, suggesting that metabolic end-products may be secreted directly into the alimentary canal (Hawkins et al. 1983).

Our observations of negative elemental fluxing from Mytilus edulis in March and October are reminiscent of measurements by Gilfillan et al. (1976). These authors documented net losses of carbon from 2 populations of the bivalve Mya arenaria during $7 \mathrm{mo}$ of the year, including the spring phytoplankton bloom. It is significant that such pronounced seasonal variations of net elemental flux, due to both varying rates of absorption and changing maintenance requirements, were apparent here despite the experimental standardization of nutrient availability and the close similarity between ambient and experimental water temperatures. Whereas conventional ideas assume a 'maximal' retention of nutrients under all circumstances, this finding suggests an endogenous influence concerning the long-term balance between aquisition and utilization of both carbon and nitrogen, as has previously been discussed for energy by Hawkins et al. (1985).

Although net fluxes of carbon and nitrogen showed the same seasonal pattern of changes, significant differences were apparent between the overall flow of each element. In particular, and regardless of season, net growth efficiencies for nitrogen regularly exceeded those for carbon. Such a conservation of nitrogen undoubtedly reflected the pronounced protein sparing' behaviour effected both by recycling of breakdown products to synthesis and a progressive reduction in fractional protein degradation with elevated net protein balance (Hawkins 1985). This behaviour was most obvious during autumn, when a positive net balance for nitrogen coincided with net losses of carbon.

Further differences between the relative utilization of nutrients were illustrated by elemental maintenance requirements. The seasonal increase in requirements during winter was more pronounced for carbon than nitrogen. For each element, these increased requirements derived from reduced gross efficiencies (i.e. the efficiency with which absorbed nutrients were used to offset net deficits), together with the concurrent demands of gametogenesis. Quite apart from possible changes in metabolic efficiency per se, the low gross efficiencies computed for mussels in winter must at least partially reflect a reduced subsidization of maintenance requirements from pre-stored reserves by starved individuals (cf. Hawkins et al. 1985). The coincident seasonal depletion of carbohydrate and lipid reserves signifies that the gross efficiency for carbon was substantially lower than for nitrogen, leading to a relatively more pronounced increase in the maintenance requirement for carbon. Such variable subsidization, which is a feature of protein sparing behaviour, represents a major influence upon changing elemental requirements. Requirements for exogenous nitrogen remained high during summer, when carbon requirements had fallen to levels equivalent to those recorded in autumn. This was in agreement with concurrent measurements showing maximum observed rates of protein synthesis (Hawkins 1985) and the deposition of that protein within adipogranular cells (Hawkins et al. 1985). A subsequent reduction in measured nitrogen requirements between summer and autumn reflected the preferential respiratory catabolism of carbon-rich reserves abundant at that time. Indeed, only $10 \%$ of total catabolic substrates were comprised of protein during autumn, relative to about $35 \%$ in March.

These findings, then, illustrate a varying balance between the elemental demands stemming from seasonal cycles of substrate storage, gametogenesis and somatic development. Assuming that all organic matter is derived from protein, Russell-Hunter (1970) calculated that the required $\mathrm{C}: \mathrm{N}$ ratio for adequate animal food intake is about $17: 1$. Results presented here indicate ingested maintenance requirements for Mytilus edulis feeding upon Phaeodactylum tricornutum that varied in $\mathrm{C}: \mathrm{N}$ ratio from at least $83: 1$ in winter to $12: 1$ during summer. Maintenance requirements computed in elemental terms will change according to the digestibility, biochemical composition and total energy content of food available. Nevertheless, it is clear that the pronounced variation of demands evidenced here, contrasted with known seasonal fluctuations in exogenous resources, may result in transient nutritional limitation of organic processes. Phytoplankton with mean $\mathrm{C}: \mathrm{N}$ ratios of 5 to $8: 1$ (Fenchel \& Jorgensen 1976, Cullen \& Horrigan 1981) are abundant during spring and autumn blooms within the English Channel (Maddock et al. 1981), whereas ratios of up to 10 to $35: 1$ may be obtained in the senescent organic tissues available in winter (RussellHunter 1970, Sakshaug \& Holm-Hansen 1977). Although $\mathrm{C}: \mathrm{N}$ ratios calculated on the basis of both protein and non-protein nitrogen within decomposing algae and detritus may have been higher still (Rice \& Tenore 1981), our data suggest that $M$. edulis from this open shore population feeding primarily upon phytoplankton were more likely to have been limited by utilizable carbon than by nitrogen. Such limitation seems especially probable during winter, when overall maintenance requirements are maximal and nutrient reserves exhausted.

Complementary evidence suggesting that growth was more likely to have been limited by available carbon than nitrogen was apparent from the relative 
degrees to which elemental maintenance requirements were satisfied. Compared with carbon, consistently greater percentages of the maintenance requirements for nitrogen were absorbed in winter $(7$ and $86 \%$, respectively), summer (158 and $297 \%$, respectively) and autumn ( 96 and $566 \%$, respectively). These results were unexpected, for it is generally assumed that production by marine herbivores may be limited by nitrogen (references reviewed by Mann 1982), with little documented evidence for similar limitation by carbon. In this context, it is interesting that elemental balances recently computed by Newell \& Field (1983) have indicated that available carbon may also limit production at the community level, in this instance among the predominantly filter feeding consumers within a kelp bed ecosystem.

Acknowledgements. We thank Dr. N. Owens and Mr. F. Staff for guidance in the use of ${ }^{15} \mathrm{~N}$ and ${ }^{14} \mathrm{C}$ isotopes, respectively, and Miss M. Day for laboratory assistance. A. H. gratefully acknowledges the support of a N.E.R.C. Research Studentship. This work forms part of the Adaptive Processes programme of the Institute for Marine Environmental Research, a component of the U.K. Natural Environment Research Council.

\section{LITERATURE CITED}

Arakawa, K. Y. (1970). Scatological studies of the Bivalvia. Adv mar. Biol. 8: 307-436

Bayne, B. L., Scullard, C. (1977). Rates of nitrogen excretion by species of Mytilus (Bivalvia: Mollusca). J. mar. biol. Ass. U.K. 57: 355-369

Bayne, B. L., Newell, R. C. (1983). Physiological energetics of marine molluscs. In: Wilbur, K. M. (ed.) The Mollusca, Vol. IV Academic Press, New York, p. 407-515

Bayne, B. L., Widdows, J. (1978). The physiological ecology of two populations of Mytilus edulis L. Oecologia (Berl.) 37 : $137-162$

Berry, P. F. (1978). Reproduction, growth and production in the mussel Perna perna (Linnaeus), on the east coast of South Africa. Investl Rep. oceanogr Res. Inst. S. Afr. Ass. mar. Biol. Res. 48: 1-28

Calow, P., Fletcher, C. R. (1972). A new radiotracer technique involving ${ }^{14} \mathrm{C}$ and ${ }^{51} \mathrm{Cr}$, for estimating the assimilation efficiencies of aquatic, primary producers. Oecologia (Berl.) 9: 155-170

Cameron, C. J., Cameron, I. F., Paterson, C. G. (1979). Contribution of organic shell matter to biomass estimates of unionid bivalves. Can. J. Zool. 57: 1666-1669

Conover, R. J. (1966). Assimilation of organic matter by zooplankton. Limnol. Oceanogr. 11: 338-345

Cullen, J. J., Horrigan, S. G. (1981). Effects of nitrate on the diurnal vertical migration, carbon to nitrogen ratio and photosynthetic capacity of the dinoflagellate Gymnodium splendens. Mar. Biol. 62: 81-89

Dinamani, P. (1969). A note on feeding and excretion in bivalves. Veliger 11: 198-199

Edwards, S. F., Welsh, B. L. (1982). Trophic dynamics of a mud snail [llyanassa obsoleta (Say)] population on an intertida] mudflat. Estuar. coast. Shelf Sci. 14: 663-686
Fenchel, T., Jorgensen, B. B. (1976). Detritus food chains of aquatic ecosystems and the role af bacteria. Adv. Microb. Ecol. 1: 1-49

Forster, J. R. M., Gabbott, P. A. (1971). The assimilation of nutrients from compounded diets by the prawns Palaemon serratus and Pandalus platyceros. J. mar biol. Ass. U.K. 51. 943-961

Gabbott, P. A., Bayne, B. L. (1973). Biochemical effects of temperature and nutritive stress on Mytilus edulis L. J. mar biol. Ass. U.K. 53: 269-286

Gallager, S. M., Turner, R. D., Berg, C. J. (1981). Physiological aspects of wood consumption, growth and reproduction in the shipworm Lyrodus pedicellatus Quatrefages (Bivalvia: Teredinidae). J. exp. mar Biol. Ecol. 52: 63-77

Gilfillan, E. S., Mayo, D., Hanson, S., Donovan, D., Jiang, L. C. (1976). Reduction in carbon flux in Mya arenaria caused by a spill of No. 6 fuel oil. Mar. Biol. 37: 115-123

Hawkins, A. J. S. (1983). Metabolic strategy in the marine mussel Mytilus edulis L. Ph.D. thesis, Univ. of Exeter

Hawkins, A. J. S. (1985). Relationships between the synthesis and breakdown of protein, dietary absorption and turnovers of nitrogen and carbon in the blue mussel, Mytilus edulis L. Oecologia (Berl.) 66: 42-49

Hawkins, A. J. S., Bayne, B. L. (1984). Seasonal variation in the balance between physiological mechanisms of feeding and digestion in Mytilus edulis (Bivalvia: Mollusca). Mar. Biol. 82: 233-240

Hawkins, A. J. S., Bayne, B. L., Clarke, K. R. (1983). Coordinated rhythms of digestion, absorption and excretion in Mytilus edulis (Bivalvia: Mollusca). Mar. Biol. 74: 41-48

Hawkins, A. J. S., Salkeld, P. N., Bayne, B. L., Gnaiger, E., Lowe, D. M. (1985). Feeding and resource allocation in the mussel Mytilus edulis: evidence for time-averaged optimization. Mar. Ecol. Prog. Ser. 20: 273-287

Houtteville, P. (1974). Contribution a l'etude cytologique et experimentale du cycle annuel du tissu de reserve du manteau de Mytilus edulis (L.). Ph.D. thesis, Univ. of Caen

Jauncey, K. (1982). The effects of varying dietary protein level on the growth, food conversion, protein utilization and body composition of juvenile Tilapias (Sarotherodon mossambicus). Aquaculture 27: 43-54

Jordan, T E., Valiela, I. (1982). A nitrogen budget of the ribbed mussel, Geukensia demissa, and its significance in nitrogen flow in a New England salt marsh. Limnol. Oceanogr. 27: 75-90

Kautsky, N. (1981). On the trophic role of the blue mussel (Mytilus edulis L.) in a Baltic coastal ecosystem and the fate of the organic matter produced by the mussels. Kieler Meeresforsch. (Sonderh.) 5: 454-461

Kiorboe, T., Mohlenberg, F., Nohr, O. (1980). Feeding, particle selection and carbon absorption in Mytilus edulis in different mixtures of algae and resuspended bottom material. Ophelia 19: 193-205

Kiorboe, T., Mohlenberg, F., Nohr, O. (1981). Effect of suspended bottom material on growth and energetics in Mytilus edulis. Mar. Biol. 61: 283-288

Kofoed, L. H. (1975). The feeding biology of Hydrobia ventrosa (Montagu). II. Allocation of the components of the carbon-budget and the significance of the secretion of dissolved organic material. J. exp. mar. Biol. Ecol. 19: 243-256

Kuenzler, E. J. (1961a). Structure and energy flow of a mussel population in a Georgia salt marsh. Limnol. Oceanogr. 6: 191-204

Kuenzler, E. J. (1961b). Phosphorus budget of a mussel population. Limnol. Oceanogr. 6: 400-415 
Liebig, J. (1840). Chemistry in its application to agriculture and physiology. Taylor and Walton, London

Maddock, L., Boalch, G. T., Harbour, D. S. (1981). Populations of phytoplankton in the western English Channel between 1964 and 1974. J. mar biol. Ass. U.K. 61: 565-583

Mann, K. H. (1982). Ecology of coastal waters, a systems approach. Blackwell, Oxford

Mathieu, M. (1979). Etude experimentale du controle neuroendocrinien de cycles de developpement de la gonade et du tissu de reserve chez la moule adulte Mytilus edulis L. (Mollusque, Lamellibranche). Ph.D. thesis, Univ. of Caen

Maynard, L. A., Loosli, J. K. (1969). Animal nutrition. 6th ed McGraw-Hill Book Co., New York

Newell, R. C., Field, J. G. (1983). The contribution of bacteria and detritus to carbon and nitrogen flow in a benthic community. Mar. Biol. Lett. 4: 23-36

Nose, T. (1967). On the metabolic fecal nitrogen in young rainbow trout. Bull. Freshwat. Fish. Res. Lab., Tokyo 17: $97-105$

Paterson, C. G. (1982). Energy distribution in biomass estimates within a freshwater bivalve community. Can. J. Zool. 60: 2753-2756

Platt, A. M. (1971). Studies on the digestive diverticula of Mytilus edulis L. Ph. D. thesis, Queens Univ., Belfast

Price, I. J., Thayer, G. W., La Croix, M. W., Montgomery, G. P. (1976). The organic content of shells and soft tissues of selected estuarine gastropods and pelecypods. Proc. natn. Shellfish. Ass. 65: 26-31

Prieur, D. (1981). Experimental studies of trophic relationships between marine bacteria and bivalve molluscs. Kieler Meeresforsch. (Sonderh.) 5: 376-383

Rice, D. L., Tenore, K. R. (1981). Dynamics of carbon and nitrogen during the decomposition of detritus derived from estuarine macrophytes. Estuar. coast. Shelf Sci. 13: $681-690$

Rodriguez-Ortega, D., Day, J. W. (1978). An ecological study of Modiolus demissus granossissimus Sowerby in Louisiana (USA). An. Centro Cienc. del Mar y Limnol. Univ. Nal. Auton. Mexico 5: 215-224

Roman, M. R. (1983). Nitrogeneous nutrition of marine invertebrates. In: Carpenter, E. J., Capone, D. G. (ed.)
Nitrogen in the marine environment. Academic Press, London, p. 347-384

Russell-Hunter, W. D. (1970). Aquatic productivity. Macmillan Co., London

Sakshaug, E., Holm-Hansen, O. (1977). Chemical composition of Skeletonema costatum (Grev.) Cleve and Pavlova (Monochrysis) lutheri (Droop) Green as a function of nitrate-, phosphate- and iton-limited growth. J. exp. mar. Biol. Ecol. 29: 1-34

Schmidt-Nielsen, K. (1977). Animal physiology: adaptation and environment. Cambridge University Press, London

Seiderer, L. J., Newell, R. C., Cook, P. A. (1982). Quantitative significance of style enzymes from two marine mussels (Choromytilus meridionalis Krauss and Perna perna Linnaeus) in relation to diet. Mar. Biol. Lett. 3: 257-272

Sokal, R. R., Rohlf, F. J. (1969). Biometry. The principle and practise of statistics in biological research. Freeman and Co., San Francisco

Stuart, V., Field, J. G., Newell, R. C. (1982). Evidence for absorption of kelp detritus by the ribbed mussel Aulacomya ater using a new ${ }^{51} \mathrm{Cr}$-labelled microsphere technique. Mar. Ecol. Prog. Ser 9: 263-271

Thompson, R. J., Bayne, B. L. (1974). Some relationships between growth metabolism and food in the mussel, Mytilus edulis. Mar. Biol. 27: 317-326

Waite, J. H. (1983). Adhesion in byssally attached bivalves. Biol. Rev. 58: 209-231

Williams, V. J., Senior, W. (1981). Effects of food restriction and body weight loss on metabolic fecal nitrogen excretion in the rat. J. Nutr. 111: 581-586

Winter, J. E. (1974). Growth in Mytilus edulis using different types of food. Ber. dt. wiss. Kommn Meeresforsch. 23: 360-375

Winter, J. E. (1976). Feeding experiments with Mytilus edulis L. at small laboratory scale. II. The influence of suspended silt in addition to aigal suspension on growth. Proc. 10th Europ. Mar. Biol. Symp., Vol. 1. Universa Press, Wetteren, p. 583-600

Winter, J. E., Acevedo, M. A., Navarro, J. M. (1984). Quempillen estuary, an experimental oyster cultivation station in southern Chile. Energy balance in Ostrea chilensis. Mar. Ecol. Prog. Ser. 20: 151-164 